\title{
Persistent Elevation of Plasma Osteopontin Levels in HIV Patients Despite Highly Active Antiretroviral Therapy
}

\author{
Haorile Chagan-Yasutan, ${ }^{1}$ Hiroki Saitoh, ${ }^{1}$ Yugo Ashino, ${ }^{1}$ Tomohiro Arikawa, ${ }^{2}$ \\ Mitsuomi Hirashima, ${ }^{2}$ Shenwei Li, ${ }^{1,3}$ Motoki Usuzawa, ${ }^{1,3}$ Shigeru Oguma, ${ }^{4}$ \\ Elizabeth Freda O.Telan, ${ }^{5}$ Chikwelu Larry $\mathrm{Obi}^{6}$ and Toshio Hattori ${ }^{1}$ \\ ${ }^{1}$ Emerging Infectious Diseases, Graduate School of Medicine, Tohoku University, Sendai, Japan \\ ${ }^{2}$ Department of Immunology and Immunopathology, Kagawa University, Takamatsu, Japan \\ ${ }^{3}$ Japan Foundation for AIDS Prevention \\ ${ }^{4}$ Medical Informatics Division, Takeda General Hospital, Kyoto, Japan \\ ${ }^{5}$ NRL-STD-AIDS Cooperative Central Laboratory, Manila, Philippines \\ ${ }^{6}$ Academic and research directorate, Walter Sisulu University, Nelson Mandela Drive, Mathatha, Eastern Cape, \\ South Africa
}

In human immunodeficiency virus (HIV) infection, not only HIV itself but also systemic immune activation plays a role in the disease progression to acquired immune deficiency syndrome (AIDS). The systemic immune activation may be present even during highly active antiretroviral therapy (HAART). An increased expression of osteopontin, a proinflammatory cytokine, during HAART was reported in lymph nodes of HIV infected individuals. Osteopontin is also known to be involved in the pathogenesis of various HAARTinduced diseases. Here, we measured osteopontin and other inflammatory markers such as neopterin and galectin-9 using serially collected plasma from patients with HIV/AIDS to find novel markers for immune activation. Four AIDS patients complicated with various opportunistic infections and one acute HIV patient were studied. Osteopontin levels (normal levels: $<820 \mathrm{ng} / \mathrm{ml}$ ) were elevated in all the patients $(1,178-2,450$ $\mathrm{ng} / \mathrm{ml}$ ). Likewise, galectin-9 levels (normal levels: $<46 \mathrm{pg} / \mathrm{ml}$ ) were elevated in all patients $(>130 \mathrm{pg} / \mathrm{ml}$ ), with the exceptionally high level in the acute HIV patient $(4,196 \mathrm{pg} / \mathrm{ml})$. Neopterin levels (normal ranges: 2-8 pmol/L) were elevated in four patients (21-99 pmol/L). After HAART, the levels of galectin-9 and neopterin apparently decreased, whereas the levels of osteopontin did not decrease. Thus, the high levels of osteopontin were sustained despite the clinical improvement. Fisher exact probability test showed that the mode of the changes was different between osteopontin and galectin-9, and between osteopontin and neopteirn $(p=0.024)$. We therefore propose that the plasma osteopontin is a useful marker of immune activation during HAART and HAART-induced side effects. — HIV/AIDS; HAART; Immune Activation; Osteopontin; Galectin-9.

Tohoku J. Exp. Med., 2009, 218 (4), 285-292. 으 2009 Tohoku University Medical Press

The mechanisms by which human immunodeficiency virus (HIV) induces the immune dysfunction clinically defined as acquired immune deficiency syndrome (AIDS) have been investigated intensively since the discovery of the virus in the early 1980s (Barré-Sinoussi et al. 1983). The levels of virus replication in infected patients have been believed to be the sole marker for the prognosis of the patients, but CD4 cell loss has been observed even in patients with low virus titers, suggesting that the virus alone was incapable of inducing AIDS and that additional factors must also play a role in the HIV-associated immunologic dysfunction (Rodriguez et al. 2006). Ascher and Sheppard (1988) hypothesized that immune activation might be an additional cause of AIDS besides the HIV RNA load. Many recent studies have indicated that immune activation, which is related to the disease progression, is caused by the synthesis of various pro-inflammatory and inflammatory cytokines (Hazenberg et al. 2003; Koblavi-Dème et al. 2003). We have also reported that the subjects with doubly infected with human T-lymphotropic virus type I (HTLV-1) and HIV-1 had the fewest CD4 cells and the highest proportion of CD8 cells with DR human leukocyte antigens (DR-Ag) (Murakami et al. 1991). Immuno-virologic studies in both SIV-infected monkeys and HIV infected individuals indicated that chronic immune activation in the context of a compromised gastrointestinal mucosal surface could result in severe immune dysfunction (Brenchley et al. 2006).

The introduction of highly active antiretroviral therapy

Received April 20, 2009; revision accepted for publication June 16, 2009. doi: 10.1620/tjem.218.285

Correspondence: Toshio Hattori, MD., Emerging Infectious Diseases, Graduate School of Medicine, Tohoku University, 1-1 Seiryo-cho,

Aoba-ku, Sendai 980-8574, Japan.

e-mail: hatori286@yahoo.co.jp 
(HAART) has dramatically reduced the viral load and mortalities of AIDS patients (Perelson et al. 1996). The threeyear observation has demonstrated that HAART improved the immune functions and reduced the mortalities in AIDS patients (Murphy et al. 2001). However, those who started CD4 count below 350 cells $/ \mathrm{mm}^{3}$ showed incomplete recovery of CD4 cells after four years of HAART, probably due to the persistent immune activation (Kelley et al. 2009). We have previously reported that recovery of central memory $\mathrm{T}$ cells is delayed after HAART and suggested that immunological abnormalities persist during the therapy (Okada et al. 2002). In addition, it has been well established that HAART induces various long-term side effects, such as osteoporosis, lipodystrophy, and cardiomyopathy (Montessori et al. 2004). The mechanisms of immune activation were studied using lymph nodes in HIV-infected individuals under HAART. Elegant studies using micro arrays of infected lymph nodes showed that HAART induced changes in the expression of many pro-inflammatory and inflammatory cytokines, and osteopontin (OPN) was found to be the only pro-inflammatory cytokine that was increased (Li et al. 2004). In the histological analysis, increased size of OPN staining in lymph node was found after 2 months of HAART in HIV infected individuals. The OPN was detected in follicular dendritic cells (FDC), which bind OPN produced by surrounding $\mathrm{T}$ cells or macrophages (Li et al. 2005). It is impossible to test dentritic cells (DCs) directly from patient's blood because most DCs reside in the lymph nodes. It was already reported that the levels of plasma OPN correlated with the neurocognitive diagnosis in
HIV-associated dementia, but those after HAART have not been reported (Burdo et al. 2008). We therefore studied the plasma levels of OPN with other inflammatory markers in HIV infected individuals with various opportunistic infections (OIs) before and after HAART.

Very recently, it was reported that OPN was involved in $\mathrm{CD}^{+} \mathrm{T}$ helper (Th1) cell lineage commitment (Shinohara et al. 2005). Plasma galectin-9 (GAL-9), which binds to T-cell immunoglobulin domain and mucin domain 3 (TIM-3), negatively regulates IFN- $\gamma$ secretion and influences the ability to induce $\mathrm{T}$ cell tolerance in both mice and man, was also studied (Anderson 2007; Anderson et al. 2007). We also measured neopterin, which is known to be increased in AIDS patients and decreased after HAART (Amirayan-Chevillard et al. 2000) along with other conventional inflammatory markers such as endotoxin and procalcitonin in this study.

\section{Clinical Courses of the Patients}

All HIV/AIDS patients are listed in Tables 1 and 2 . Patients one through five were enrolled in this study and were hospitalized during Oct. 2007 to Jan. 2008 in Tohoku University Hospital. Patients 2-5 were severely ill when enrolled in these studies due to acute infection, concomitant OIs or tumor. The patients were treated first for their OIs or tumor followed by HAART.

Patient 1 was asymptomatic HIV infection that was co-infected with Hepatitis B virus (HBV). HAART with Atazanavir (ATV) and Tenofovir/Emtricitabine (TDF/FTC) was necessary in this patient because he was given

Table 1. Patients profile.

\begin{tabular}{|c|c|c|c|c|c|c|c|}
\hline Patients & Gender & $\begin{array}{l}\text { Age } \\
(\mathrm{yr})\end{array}$ & Diagnosis & $\begin{array}{l}\text { Complications } \\
\text { before HAART }\end{array}$ & $\begin{array}{c}\text { Complications } \\
\text { after HAART }\end{array}$ & $\begin{array}{c}\text { CD4 count } \\
(\mu 1)\end{array}$ & $\begin{array}{l}\text { RNA-load } \\
\text { (copies/ml) }\end{array}$ \\
\hline 1 & Male & 40 & $\mathrm{AC}$ & HBV & Skin rash, Fever & 378 & $2.6 \times 10^{3}$ \\
\hline 2 & Male & 27 & Acute HIV & Syphilis*, Fever & Fever & 67 & $3.1 \times 10^{5}$ \\
\hline 3 & Male & 34 & AIDS & PCP & Varicella & 25 & $2.0 \times 10^{4}$ \\
\hline 4 & Male & 47 & AIDS & MTB & Fever & 2.7 & $6.2 \times 10^{4}$ \\
\hline 5 & Male & 35 & AIDS & $\mathrm{KS}$ & Recurrence & 244 & $5.4 \times 10^{1}$ \\
\hline
\end{tabular}

Definition of abbreviations: HAART, highly active antiretroviral therapy; AC, asymptomatic carrier; HBV, Hepatitis B virus; HIV, human immunodeficiency virus; AIDS, acquired immunodeficiency syndrome; PCP, pneumocystis pneumonia; MTB, miliary tuberculosis; KS, kaposi's sarcoma.

*Remission at this study.

Table 2. Profiles of stable patients under HAART.

\begin{tabular}{ccccccc}
\hline Patients & Gender & $\begin{array}{c}\text { Age } \\
(\mathrm{yr})\end{array}$ & $\begin{array}{c}\text { Months } \\
\text { after HAART }\end{array}$ & $\begin{array}{c}\text { Complications } \\
\text { before HAART }\end{array}$ & $\begin{array}{c}\text { CD4 count } \\
(\mu \mathrm{l})\end{array}$ & $\begin{array}{c}\text { RNA-load } \\
(\text { copies/ml })\end{array}$ \\
\hline 6 & Male & 29 & 58 & PCP & 384 & $<50$ \\
7 & Male & 54 & 35 & PCP $*$ DM & 229 & $<50$ \\
8 & Male & 62 & 15 & $\begin{array}{l}\text { Esophagus } \\
\text { Candidiasis* }\end{array}$ & 392 & $<50$ \\
\hline
\end{tabular}

Definition of abbreviations: HAART, highly active antiretroviral therapy; AIDS, acquired immunodeficiency syndrome; PCP, pneumocystis pneumonia; DM, diabetes mellitus;

* Remission at this study. 
Entecavir (ETV) which reduced not only the HBV-DNA virus load (from 7.5 to 3.7 Log-copies/ml) but also the HIVRNA load (from 24,000 to 2,600 copies/ml). Additionally, the appearance of M184 mutations in reverse transcriptase was detected (Fukushima et al. 2008). After HAART, the patient suffered from severe skin lesions associated with fever and increased levels of alanine aminotransferase (ALT) from day 11. Prednisolone (PSL) was given $(30 \mathrm{mg} /$ day followed by tapering) for the inflammatory response which subsided at day 18 despite the continuing HAART. The viral RNA levels became 97 copies/ml two weeks after HAART and the HBV-DNA decreased from 3.7 to $2.6 \mathrm{log}$ copies/ml during this study. The CD4 count decreased to $236 / \mu 1$ at day 14 when the skin rash appeared followed by a rapid increase (544/ $\mu 1$ at day 27). ETV was stopped at day 52 but the HBV-DNA levels continued to decrease to 2.3 log-copies/ml and the HIV virus load slightly increased to 720 copies/ml at day 139.

Patient 2 had been transferred to our hospital under the diagnosis of fever of unknown origin and skin rash, and he was diagnosed as acute HIV infection due to the high HIV viral load and very low CD4 counts. HAART with Nelfinavir (NFV) and Lamivudine/Stavudine (3TC/d4T) was initiated and it immediately reduced the fever, skin rash and ALT, and the virus load decreased from $3.1 \times 10^{5}$ to 2.4 $\times 10^{3}$ copies/ml within 1 month. The patient showed only mild nausea by HAART. PSL was given for the prevention of Immune Reconstitution Inflammatory Syndrome (IRIS) (Saitoh et al. 2009).

In patients 3-5, HAART was started after the treatment for OIs or tumor. Patient 3 was diagnosed as AIDS associated with PCP and was treated with co-trimoxazole (TMP/ SMX) before HAART. After HAART (NFV+3TC/d4T), he developed diarrhea (day 2), abdominal pain and skin eruptions, and he was diagnosed as varicella zoster virus (VZV) based on a PCR method (day 5), and he also developed fever at day 13. These symptoms disappeared by PSL treatment. HAART was temporarily discontinued due to the abdominal pain, and a rapid decline of HIV RNA and an increase of CD4 cell counts were also seen (Fig. 1A).

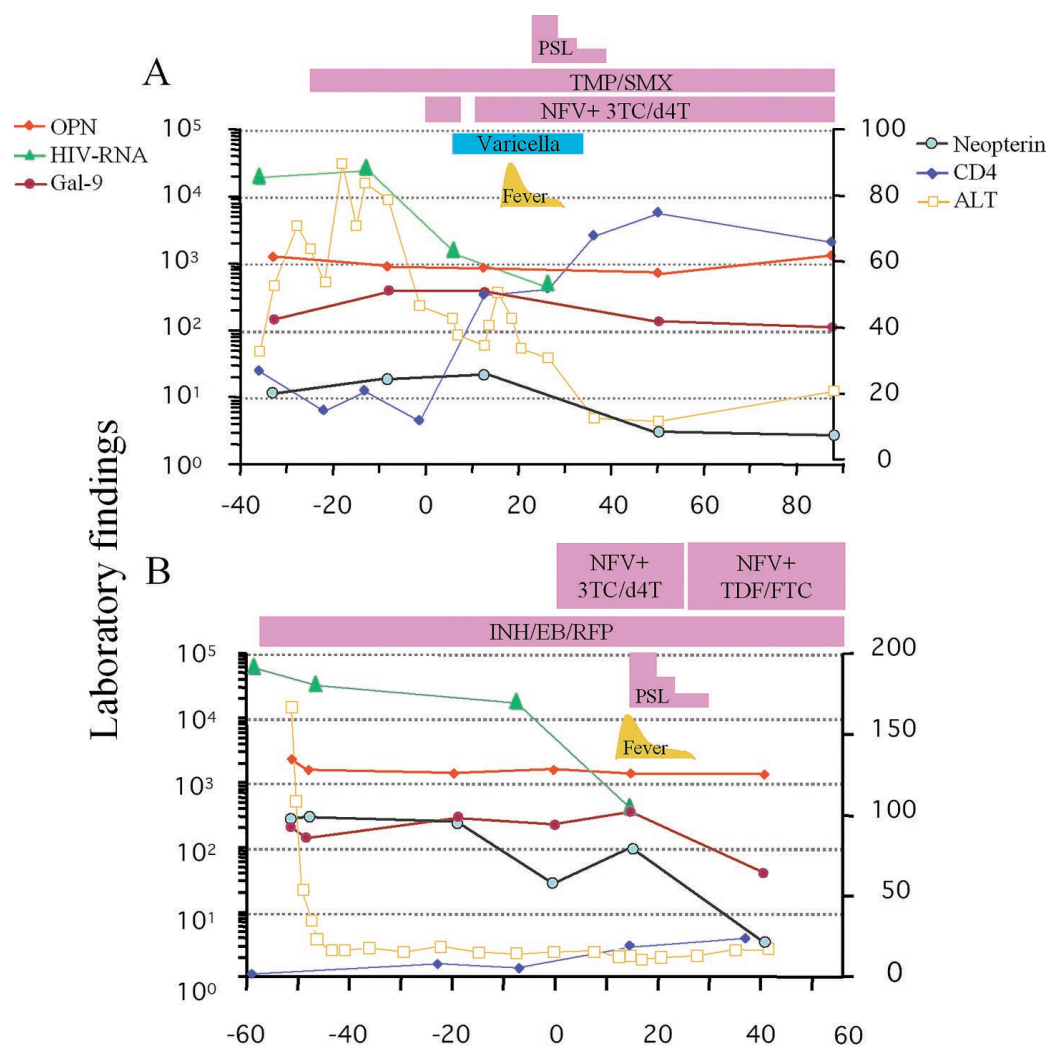

Days after HAART

Fig. 1. Clinical courses of patients 3 and 4 .

A. Patient 3 was diagnosed as AIDS/PCP and was treated with co-trimoxazole (TMP/SMX) before HAART. After HAART (NFV+3TC/d4T), he developed diarrhea (day 2), abdominal pain and skin eruptions, and he was diagnosed as varicella zoster virus at day 5; he also developed fever at day 13. These symptoms disappeared by prednisolone (PSL) treatment. HAART was temporarily discontinued due to the abdominal pain, and a rapid decline of HIV RNA and an increase of CD4 cell counts were also seen. B. patient 4, miliary pulmonary tuberculosis (MTB) was successfully treated by isoniazid (INH), ethambutol (EB) and rifampicin (RFP). HAART (NFV+3TC/d4T) caused a skin rash at day 7 , diarrhea at day 10 and high fever at days 12 to 28. PSL was given followed by tapering of the dose, and the HAART regimen was changed to NFV and TDF/FTC. 
In patient 4 , miliary pulmonary tuberculosis (MTB) was successfully treated by isoniazid (INH), ethambutol (EB) and rifampicin (RFP). HAART $(\mathrm{NFV}+3 \mathrm{TC} / \mathrm{d} 4 \mathrm{~T})$ caused a skin rash at day 7 , diarrhea at day 10 and high fever at days 12 to 28 . PSL (40 mg/day) was given followed by tapering of the dose, and the HAART regimen was changed to NFV and TDF/FTC (Fig. 1B).

Patient 5 was associated with Kaposi's sarcoma (KS), and showed remarkable skin lesions associated with massive pleural effusion (March, 2007). He was treated with pegylated liposomal doxorubicin (DOX-SL) and the KS lesions were gradually improved by HAART (NFV+3TC/ $\mathrm{d} 4 \mathrm{~T})$. The patient was discharged in June, 2007. Pleural effusion and KS lesions were noticed at the outpatient department (OPD) and he was readmitted (July, 2007). HAART was discontinued at day -35 due to probable IRIS and he received the second HAART $(\mathrm{NFV}+3 \mathrm{TC} / \mathrm{d} 4 \mathrm{~T})$ with DOX-SL therapy. The HIV-RNA levels became $<50$ copies/ml but the CD4 counts did not increase significantly.

Patients 6-8 were seen in the OPD because of their stable conditions (HIV-RNA level $<50$ copies/ml) (Table 2).

\section{Materials and Methods}

Subjects: We designed a longitudinal study using 5 HIV/AIDS patients in Tohoku University Hospital between October 2007 and January 2008. These patients were clinically diagnosed as AIDS and admitted to the hospital for treatment (Table 1). Three other patients who attended the OPD and were treated with HAART for 1-5 years were also evaluated (patients 6-8) (Table 2). Medical histories were taken from the enrolled patients and all of them underwent physical and laboratory examinations including HIV-RNA load and CD4 counts. As normal controls, plasma samples were collected from thirty healthy individuals ( 25 to 58 years old). All work was conducted in accordance with the Declaration of Helsinki. The study was approved by the Ethics Committee of Tohoku University Hospital (2007-257; 2008-135). We obtained written informed consent from all the enrolled patients.

Clinical data: Anti HIV-1 antibody, viral RNA levels, CD4 cell numbers, ALT and other laboratory markers were measured in Tohoku University Hospital.

Inflammatory markers: Blood was collected in tubes containing ethylenediaminetetraacetic acid (EDTA) to give a final concentration of $0.1 \%$. Plasma was obtained by centrifugation of $2,000 \mathrm{rpm}$ for 10 minutes at $4^{\circ} \mathrm{C}$ and was aliquoted to cryotubes (Corning 430289) and stored at $-80^{\circ} \mathrm{C}$ until use. Repeated thawing was avoided. The levels of OPN in plasma were measured using a human osteopontin ELISA kit (Immuno-Biological Laboratories (IBL), Takasaki, Japan) according to the manufacturer as described below (Kim et al. 2002). The standard and test samples were diluted with dilution fluid (1\% BSA and $0.05 \%$ Tween 20 in phosphate buffered saline (PBS)), added to pre-coated plates and incubated at $37^{\circ} \mathrm{C}$ for 1 hour. After washing 7 times with $0.05 \%$ Tween 20 , HRP conjugated mouse monoclonal antihuman OPN (IBL, 10A16) was added followed by incubation for 30 $\min$ at $4^{\circ} \mathrm{C}$. The reaction was developed by $3,3^{\prime}, 5,5^{\prime}$-Tetramethylbenzidine solution and was stopped by stop solution which contained $1 \mathrm{~N} \mathrm{H}_{2} \mathrm{SO}_{4}$. The result was read by a SOFTmax PRO reader (Molecular Devices, Orleans Drive Sunnyvale, CA) and was expressed as ng/ml.

The GAL-9 concentration in plasma was quantified by ELISA
(Galpharam Co. Ltd, Takamatsu, Japan) (Seki et al. 2007). In brief, 96-well plates (Nunc, Rockild, Denmark) were coated with antihuman GAL-9 mAb (9S2-3), blocked with 3\% fetal bovine serum containing $0.05 \%$ Tween 20 in PBS, then incubated with test sample at $37^{\circ} \mathrm{C}$ for $1 \mathrm{~h}$. After several washings, GAL-9 that remained in the wells was recognized by polyclonal anti-human GAL-9 antibody conjugated with biotin using EZ-Link Sulfo-NHS-Biotin reagent (Pierce, Suwanee, GA). Quantification was carried out using streptavidine-conjugated horseradish peroxidase (Invitorogen, Carlsbad, CA) and the colorimetric substrate tetramethylbenzidine, and the optical density was read with a microplate spectrophotometer (Bio-Rad, Hercules, CA). The results of OPN and gelactin-9 were expressed as the average of triplicate samples. Neopterin and procalcitonin were measured by high-performance-liquid-chromatography (Hausen et al. 1982) and chemiluminescent enzyme immunoassay (Aikawa et al. 2005) at a special reference laboratory (SRL) (Hachiouji, Japan). Endotoxin was also measured at SRL using a Limulus amebocyte lysate test with a slight modification.

According to the SRL, the normal values of inflammatory markers were neopterin $2-8 \mathrm{pmol} / \mathrm{L}$, procalcitonin $<0.5 \mathrm{ng} / \mathrm{ml}$ and endotoxin $<1.0 \mathrm{pg} / \mathrm{ml}$. Those of OPN and GAL-9 were determined based on the means \pm standard derivation (SD) of thirty normal volunteers as follows: OPN $<820 \mathrm{ng} / \mathrm{ml}$, GAL- $9<46 \mathrm{pg} / \mathrm{ml}$.

Statistical analysis: Chi-square contingency table analysis was used for estimating differences among OPN, GAL-9 and neopterin according to the changes after HAART. Two tailed binomial test was used for estimating the significance of changes in each variable.

\section{Results}

Inflammatory markers: Five inflammatory markers were examined in all patients. The titers of inflammatory markers on admission are listed in Table 3.

Procalcitonin and endotoxin was not detected in any of the eight patients. Compared with the healthy control group, the neopterin levels were elevated in four out of 5 patients and the levels of GAL-9 and OPN were elevated in all the patients (Table 3 ).

Changes of inflammatory markers by treatment of OIs: It is interesting that three pro-inflammatory markers showed different profiles during the treatment of PCP (patient 3) (Fig. 1A) and MTB (patient 4) (Fig. 1B). In these patients, the OPN levels (Fig. 2A) decreased by this treatment, but the GAL-9 (Fig. 2B) and neopterin (Fig. 2C) levels were increased.

Changes of Inflammatory markers after HAART: The levels of GAL-9 (Fig. 2B) and neopterin (Fig. 2C) became almost normal after HAART, but a decrease of the OPN (Fig. 2A) levels was not observed during HAART. Slight increases in the levels of GAL-9 and neopterin were also seen only in patient 4 immediately after HAART (Fig. 1B).

OPD patients: In three OPD patients, patients 7 and 8 still showed slight increases of OPN. Patient 7 was suffering from diabetes mellitus. Patient 8 did not show any significant symptoms.

Statistical analysis: The changes of the levels of OPN, GAL-9, and neopterin before and after HAART were compared. The sample before HAART was not available 
Table 3. levels of inflammatory markers of patients on admission.

\begin{tabular}{|c|c|c|c|c|c|}
\hline Patients & $\mathrm{OPN}(\mathrm{ng} / \mathrm{ml})^{\mathrm{a}}$ & GAL-9 $(\mathrm{pg} / \mathrm{ml})^{\mathrm{b}}$ & Neopterin $(\mathrm{pmol} / \mathrm{L})^{\mathrm{c}}$ & Procalcitonin $(\mathrm{ng} / \mathrm{ml})^{\mathrm{d}}$ & Endotoxin $(\mathrm{pg} / \mathrm{ml})^{\mathrm{e}}$ \\
\hline 1 & 1621 & 130 & 8 & $<0.1$ & $<0.8$ \\
\hline 2 & 1241 & 4196 & 64 & 0.3 & $<0.8$ \\
\hline 3 & 1178 & 138 & 21 & $<0.1$ & $<0.8$ \\
\hline 4 & 2450 & 213 & 99 & $<0.1$ & $<0.8$ \\
\hline 5 & 1522 & 272 & 22 & $<0.1$ & $<0.8$ \\
\hline
\end{tabular}

Normal values in this study are: a $<820 \mathrm{ng} / \mathrm{ml}$; $<46 \mathrm{pg} / \mathrm{ml} ; \mathrm{c} 2-8 \mathrm{pmol} / \mathrm{L} ; \mathrm{d}<0.5 \mathrm{ng} / \mathrm{ml}$; e $<1.0 \mathrm{pg} / \mathrm{ml}$.

Table 4. The numbers of the analyzed data of inflammatory markers after HAART.

\begin{tabular}{lccc}
\hline $\begin{array}{c}\text { Inflammatory } \\
\text { marker }\end{array}$ & $\begin{array}{c}\text { Total } \\
\text { points }\end{array}$ & $\begin{array}{c}\text { Increased } \\
\text { points }\end{array}$ & $\begin{array}{c}\text { Decreased } \\
\text { points }\end{array}$ \\
\hline Osteopontin & 11 & 7 & 4 \\
Galectin-9 & 11 & 1 & 10 \\
Neopterin & 11 & 1 & 10 \\
\hline
\end{tabular}

Note: Patient 1 was not included because data before HAART are not available

in patient 1 . Eleven points from 4 patients after HAART were compared with the levels before HAART (day -1 ). Increases of OPN were found in seven points, but only in one point for GAL-9 and neopterin (Table 4). Fisher exact probability test showed that the changing mode was different both between OPN and GAL-9, and OPN and neopterin $(p=0.024$, two-tail).

\section{Discussion}

We investigated five inflammatory markers before and after HAART in AIDS patients. In our study, procalcitonin and endotoxin was positive in none of the patients. In contrast to these bacteria-related immune activation markers, three other pro-inflammatory markers, GAL-9, neopterin and OPN, were found to be positive in these patients. But, the changing modes of OPN were different from those of GAL-9 and neopterin.

The concomitant OIs were treated first and during this chemotherapeutic period OPN decreased in patients 3 (PCP) and 4 (MTB), but GAL-9 and neopterin increased. The level of neopterin was normal in asymptomatic HIV infection (patient1) as described before (Zangerle et al. 1998). After HAART, The levels of GAL-9 and neopterin decreased, but the OPN levels did not decrease and remained moderately high. It is known that the neopterin levels are decreased by corticosteroid treatment (Hamerlinck et al. 1999). In our study, PSL was also given to prevent IRIS in patients1-4 for at least one week, and the drug may have decreased the levels of neopterin and GAL-9. It is of note that the persisting high levels of OPN after HAART were unique because our previous study using malaria patients showed that high levels of OPN became normal within one week after treatment (Jitthiang et al. 2008), furthermore, a significant fall in the plasma OPN levels after treatment of TB patients was reported (Koguchi et al. 2003).

It is also interesting that GAL-9 was very high in the acute HIV patient (patient 2) but decreased rapidly by HAART. Further studies will be necessary to understand the biological significance of the increased GAL-9 levels in acute HIV infection.

The reasons for the persistent high levels of OPN are not clear. OPN is one of the small integrin-binding ligand N-linked glycoproteins (SIBLINGs) (Fisher et al. 2001), and it has been known to be synthesized by many different cells, such as T cells (Ashkar et al.2000), macrophages (Giachelli et al. 1998), plasmacytoid dendritic cells (pDC) (Shinohara et al. 2006), endothelial cells (O'Brien et al. 1994), and smooth muscle cells (Jalvy et al. 2007). Therefore, the possible sources of the plasma OPN after HAART could be activated $T$ cells and antigen presenting cells (pDC, macrophage) because immune activation are also exist after HAART (Hunt et al. 2003). In addition, the OPN levels were still elevated in two patients at OPD who received HAART for more than one year, and it should be noted that the CD4 counts from these two patients never exceeded $400 / \mu 1$. Finally, it has been well established that HAART induces various long term side effects, such as osteoporosis, lipodystrophy, and cardiomyopathy (Montessori et al. 2004). The high levels of OPN could be one of the responsible agents of the various side effects of HAART such as osteoporosis and cardiovasucular diseases, because the involvement of OPN in these diseases is also well known (Tamura et al. 2003; Ramankulov et al. 2007). Recently, a persistent elevation of soluble vascular adhesion molecule-1 (VCAM-1) upon antiretroviral therapy despite viral suppression was reported, and such an elevation was claimed to be the cause of the cardiovascular risk of HAART therapy (Papasavvas et al. 2008). It is also well known that both OPN and VCAM-1 binds to the integrin $\alpha 9 \beta 1$ (Smith et al. 1996; Taooka et al. 1999).

Very recently, early introduction of HAART was found to significantly decrease mortality and morbidity compared to deferred treatment in HIV/AIDS patients at 5 years of observation (Kitahata et al. 2009), although it is not clear whether early treatment was associated with more frequent long-term side effects or not. It should be considered whether the occurrence of side effects could be lowered by reducing the production of OPN and/or VCAM-1 during HAART. 
A
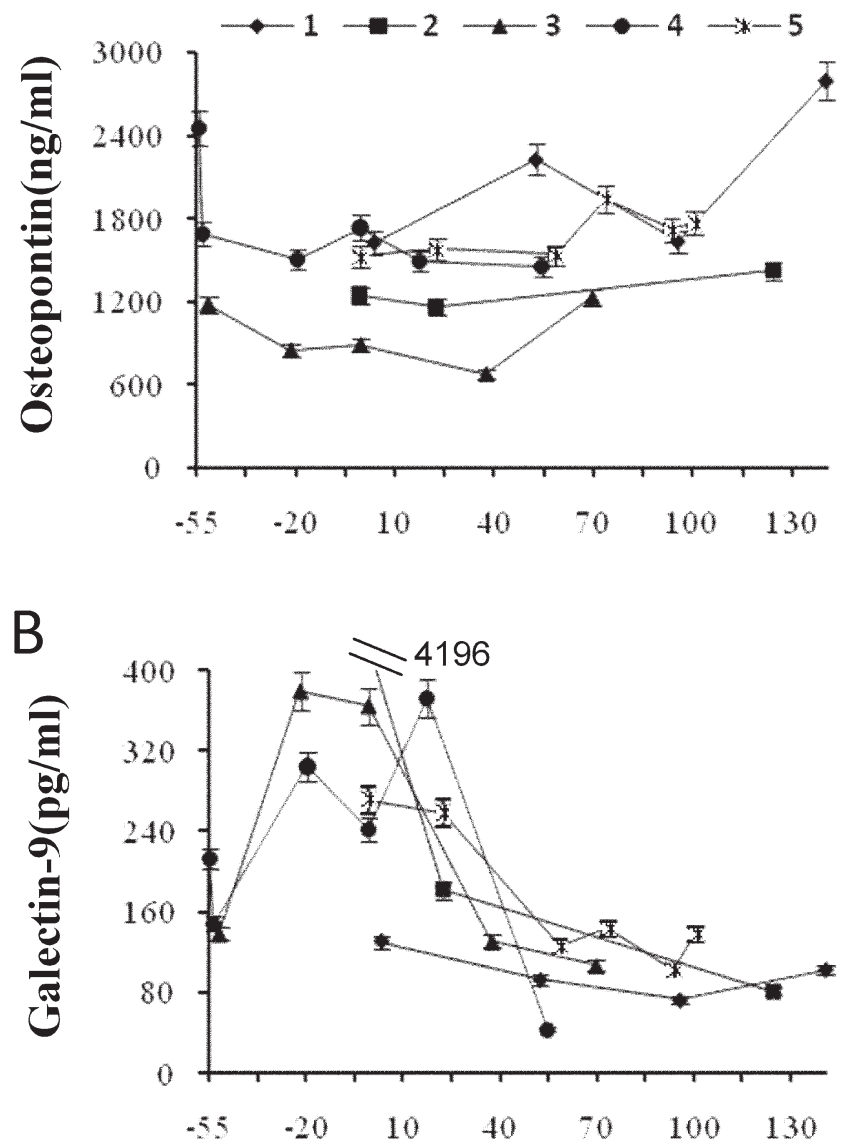

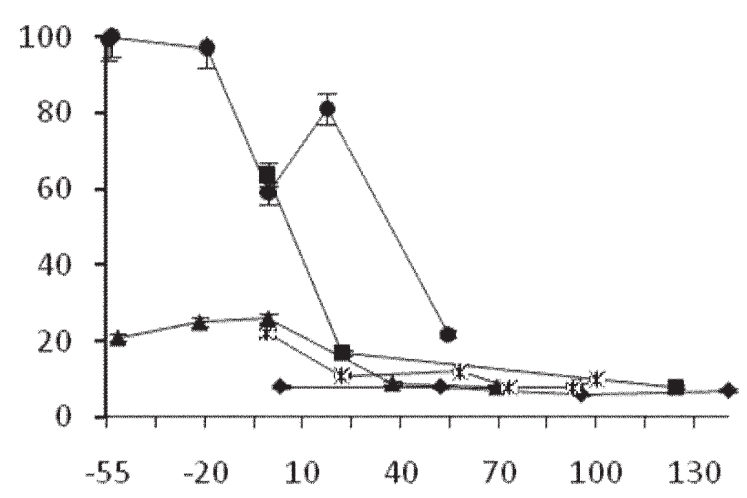

\section{Days after HAART}

Fig. 2. Changes of inflammatory markers of 5 patients before and after HAART.

The changes of the levels of OPN, GAL-9 and neopterin before and after HAART were compared. Fisher exact probability test showed that the changing mode was different both between OPN and GAL-9, and OPN and neopteirn ( $p=0.024$, two-tail). Normal ranges of these inflammatory marker's were as follows: A. OPN $<820$ $\mathrm{ng} / \mathrm{ml}$; B. GAL-9 < $46 \mathrm{pg} / \mathrm{ml}$; C. Neopterin $2-8 \mathrm{pmol} / \mathrm{L}$. The error bar indicates standard deviation (s.D.).
Since a limitation of this study is the low numbers of patients, the involvement of immune activation-induced OPN in various side effects of HAART should be carefully investigated with appropriate controls in a large number of patients in Africa where HAART was introduced very recently and 3 million people received HAART accounting for 30\% of those needing such treatment (Ford et al. 2009), and many patients still take herbal medicine, which was shown by us to contain an anti-HIV compound (Theo et al. 2009). It is also interesting to investigate whether anti-HIV herbal medicine could increase the OPN production or cause side effects like HAART.

Taken together, we investigated 5 different inflammatory markers before and after HAART. The levels of GAL-9 and neopterin decreased after HAART but persistent elevations of the OPN levels were observed suggesting the possible involvement of OPN in immune activation during HAART and HAART-induced side effects.

\section{Acknowledgment}

We would like to thank the AIDS patients who participated in the study. We are grateful to Prof. Toshimitsu Uede and Dr. Eiichi Kodama for critical reading of the manuscript.

This work was supported by Grant-in-Aid for Scientific Research from JSPS and the Scientific Research Expenses for Health and Welfare Program from the Ministry of Health and Welfare, Japan. The authors are also grateful for a collaborative grant from Banyu Pharmaceutical Co. Ltd..

\section{References}

Aikawa, N., Fujishima, S., Endo, S., Sekine, I., Kogawa, K., Yamamoto, Y., Kushimoto, S., Yukioka, H., Kato, N., Totsuka, K., Kikuchi, K., Ikeda, T., Ikeda, K., Harada, K. \& Satomura, S. (2005) Multicenter prospective study of procalcitonin as an indicator of sepsis. J. Infect. Chemother., 11, 152-159.

Amirayan-Chevillard, N., Tissot-Dupont, H., Obadia, Y., Gallais, H., Mege, J.L. \& Capo, C. (2000) Highly active antiretroviral therapy (HAART) and circulating markers of immune activation: specific effect of HAART on neopterin. Clin. Diagn. Lab. Immunol., 7, 832-834.

Anderson, A.C., Anderson, D.E., Bregoli, L., Hastings, W.D., Kassam, N., Lei, C., Chandwaskar, R., Karman, J., Su, E.W., Hirashima, M., Bruce, J.N., Kane, L.P., Kuchroo, V.K. \& Hafler, D.A. (2007) Promotion of tissue inflammation by the immune receptor Tim-3 expressed on innate immune cells. Science, 318, 1141-1143.

Anderson, D.E. (2007) TIM-3 as a therapeutic target in human inflammatory diseases. Expert Opin. Ther. Targets, 11, 10051009.

Ascher, M.S. \& Sheppard, H.W. (1988) AIDS as immune system activation: a model for pathogenesis. Clin. exp. Immunol., 73, 165-167.

Ashkar, S., Weber, G.F., Panoutsakopoulou, V., Sanchirico, M.E., Jansson, M., Zawaideh, S., Rittling, S.R., Denhardt, D.T., Glimcher, M.J. \& Cantor, H. (2000) Eta-1 (Osteopontin): An early component of type-1 (Cell-Mediated) immunity. Science, 287, 860-864.

Barré-Sinoussi, F., Chermann, J.C., Rey, F., Nugeyre, M.T., Chamaret, S., Gruest, J., Dauguet, C., Axler-Blin, C., Vézinet-Brun, F., Rouzioux, C., Rozenbaum, W. \& Montagnier, L. (1983) Isolation of a T-lymphotropic retrovirus from a patient at risk for acquired immune deficiency syndrome (AIDS). Science, 220, 868-871. 
Brenchley, J.M., Price, D.A., Schacker, T.W., Asher, T.E., Silvestri, G., Rao, S., Kazzaz, Z., Bornstein, E., Lambotte, O., Altmann, D., Blazar, B.R., Rodrigeuz, B., Teixeira-Johnson, L., Landay, A., Martin, J.N., Hecht, F.M., Picker, L.J., Lederman, M.M., Deeks, S.G. \& Douek, D.C. (2006) Microbial translocation is a cause of systemic immune activation in chronic HIV infection. Nat. Med., 12, 1365-1371.

Burdo, T.H., Ellis, R.J. \& Fox, H.S. (2008) Osteopontin is increased in HIV-associated dementia. J. Infect. Dis., 198, 715-722.

Fisher, L.W., Torchia, D.A., Fohr, B., Young, M.F. \& Fedarko, N.S. (2001) Flexible structures of SIBLING proteins, bone sialoprotein, and osteopontin. Biochem. Biophys. Res. Commun. 280, 460-465.

Ford, N., Mills, E. \& Calmy, A. (2009) Rationing antiretroviral therapy in Africa-treating too few, too late. N. Engl. J. Med., 360, 1808-1810.

Fukushima, K., Ueno, K., Inoue, J., Wakui, Y., Obara, N., Kimura, O., Kido, O., Nakagome, Y., Kakazu, E., Matsuda, Y., Kogure, T., Kondo, Y., Nagasaki, F., Yamagiwa, Y., Ashino, Y. \& Shimosegawa, T. (2008) A case of HIV co-infected with HBV precore core deletion mutant treated by Entecavir. Hepatol. Res., 38, 842-846.

Giachelli, C.M., Lombardi, D., Johnson, R.J., Murry, C.E. \& Almeida, M. (1998) Evidence for a role of osteopontin in macrophage infiltration in response to pathological stimuli in Vivo. Am. J. Pathol., 152, 353-358.

Hamerlinck, F.F.V., Klatser, P.R., Walsh, D.S., Bos, J.D., Walsh, G.P. \& Faber, W.R. (1999) Serum neopterin as a marker for reactional states in leprosy. FEMS Immunol. Med. Microbiol., 24, 405-409.

Hausen, A., Fuchs, D., Konig, K. \& Wachter, H. (1982) Determination of neopterin in human urine by reversed phase highperformance liquid chromatography. J. Chromatogr., 227, 61-70.

Hazenberg, M.D., Otto, S.A., van Bentheme, B.H.B., Roos, M.Th.L., Coutinhoe, R.A., Lange, J.M.A., Hamann, D., Prins, M. \& Miedema, F. (2003) Persistent immune activation in HIV-1 infection is associated with progression to AIDS. AIDS, 17, 1881-1888.

Hunt, P.W., Martin, J.F., Sinclair, E., Bredt, B., Hagos, E., Lampiris, H. \& Deeks, S.G. (2003) T cell activation is associated with lower $\mathrm{CD}^{+} \mathrm{T}$ cell gains in human immunodeficiency virus-infected patients with sustained viral suppression during antiretroviral therapy. J. Infect. Dis., 187, 1534-1543.

Jalvy, S., Renault, M.A., Leen, L.S.L., Belloc, I., Reynaud, A., Gadeau, A.P. \& Desgranges, C. (2007) CREB mediates UTPdirected arterial smooth muscle cell migration and expression of the chemotactic protein osteopontin via its interaction with activator protein-1 sites. Circ. Res., 100, 1292-1299.

Jitthiang, P., Chagan-Y, H., Ashino, Y., Li, S., Tangpukdee, N., Usami, O., Promjunyakul, W., Looareesuwan, S., Krudsood, S. \& Hattori, T. (2008) High osteopontin (OPN) response against plasmodium falciparum in Thailand-Myanmar border. JITMM (Oct. Bangkok), 124.

Kelley, C.F., Kitchen, C.M.R., Hunt, P.W., Rodriguez, B., Hecht, F.M., Kitahata, M., Crane, H.M., Willig, J., Mugavero, M., Saag, M., Martin, J.N. \& Deeks, S.G. (2009) Incomplete peripheral $\mathrm{CD}^{+}$cell count restoration in HIV-infected patients receiving long-term antiretroviral treatment. Clin. Infect. Dis., 48, 787-794.

Kim, J.H., Sakates, S.J., Uede, T., Wong, K.K., Schorge, J.O., Feltmate, C.M., Berkowitz, R.S., Cramer, D.W. \& Mok, S.C. (2002) Osteopontin as a potential diagnostic biomarker for ovarian cancer. JAMA, 287, 1671-1679.

Kitahata, M.M., Gange, S.J., Abraham, A.G., Merriman, B., Saag, M.S., Justice, A.C., Hogg, R.S., Deeks, S.G., Eron, J.J., Brooks, J.T., Rourke, S.B., Gill, M.J., Bosch, R.J., Martin, J.N., Klein, M.B., Jacobson, L.P., Rodriguez, B., Sterling, T.R.,
Kirk, G.D., Napravnik, S., Rachils, A.R., Calzavara, L.M., Horberg, M.A., Silverberg, M.J., Gebo, K.A., Goedert, J.J., Benson, C.A., Collier, A.C., Rompaey, S.E.V., Crane, H.M., Mckaig, R.G., Lau, B., Freeman, A.M. \& Moore, R.D. (2009) Effect of early versus deferred antiretroviral therapy for HIV on survival. N. Engl. J. Med., 360, 1815-1826.

Koblavi-Dème, S., Maran, M., Kabran, N., Borget, M.Y., Kalou, M., Kestens, L., Maurice, C., Sassan-Morokro, M., Ekipini, E.R., Roels, T.H., Chorba, T. \& Nkengasong, J.N. (2003) Changes in levels of immune activation and reconstitution markers among HIV-1-infected Africans receiving antiretroviral therapy. AIDS, 17 (suppl 3), S17-S22.

Koguchi, Y., Kawakami, K., Uezu, K., Fukushima, K., Kon, S., Maeda, M., Nakamoto, A., Owan, I., Kuba, M., Kudeken, N., Azuma, M., Yara, S., Shinzato, T., Higa, F., Tateyama, M., Kadota, J., Mukae, H., Kohno, S., Uede, T. \& Saito, A. (2003) High plasma osteopontin level and its relationship with interleukin-12-mediated type $1 \mathrm{~T}$ helper cell response in tuberculosis. Am. J. Respir. Crit. Care Med., 167, 1355-1359.

Li, Q., Lifson, J.D., Duan, L., Schacker, T.W., Reilly, C., Carlis, J., Estes, J.D. \& Haase, A.T. (2005) Potential roles of follicular dendritic cell-associated osteopontin in lymphoid follicle pathology and repair and in B cell regulation in HIV-1 and SIV infection. J. Infect. Dis., 192, 1269-1276.

Li, Q., Schacker, T., Carlis, J., Beilman, G., Nguyen, P. \& Haase, A.T. (2004) Functional genomic analysis of the response of HIV-1-infected lymphatic tissue to antiretroviral therapy. $J$. Infect. Dis., 189, 572-582.

Montessori, V., Press, N., Harris, M., Akagi, L. \& Montaner, J.S.G. (2004) Adverse effects of antiretroviral therapy for HIV infection. CMAJ, 170, 229-238.

Murakami, T., Hattori, T., Maeda, Y., Matsushita, S., Kannagi, M., Sagawa, K. \& Takatuski, K. (1991) Immunological and virological status of a hemophiliac infected with human $\mathrm{T}$ cell lymphotropic virus type 1 and human immunodeficiency virus type 1 , and results of therapy. Int. J. Hematol., 54, 85-90.

Murphy, E.L., Collier, A.C., Kalish, L.A., Assmann, S.F., Para, M.F., Flanigan, T.P., Kumar, P.N., Mintz, L., Wallach, F.R. \& Nemo, G.J. (2001) Highly active antiretroviral therapy decreases mortality and morbidity in patients with advanced HIV disease. Ann. Intern. Med., 135, 17-26.

O’Brien, E.R., Garvin, M.R., Stewart, D.K., Hinohara, T., Simpson, J.B., Schwartz, S.M. \& Giachelli, C.M. (1994) Osteopontin is synthesized by macrophage, smooth muscle, and endothelial cells in primary and restenotic human coronary atherosclerotic plaques. Arterioscler. Thromb., 14, 1648-1656.

Okada, S., Kikuchi, M., Hasegawa, H., Ishikawa, M., Ohno, I., Kaku, M. \& Hattori, T. (2002) Delayed recovery of effector memory CD4+ T cells by highly active antiretroviral therapy in a patient with HIV-1 infection. Tohoku J. Exp. Med., 196(3), 213-218.

Papasavvas, E., Azzoni, L., Pistilli, M., Hancock, A., Reynolds, G., Gallo, C., Ondercin, J., Kostman, J.R., Mounzer, K., Shull, J. \& Montaner, L.J. (2008) Increased soluble vascular cell adhesion molecule-1 plasma levels and soluble intercellular adhesion molecule-1 during antiretroviral therapy interruption and retention of elevated soluble vascular cellular adhesion molecule-1 levels following resumption of antiretroviral therapy. AIDS, 22, 1153-1161.

Perelson, A.S., Neumann, A.U., Markowitz, M., Leonard, J.M. \& Ho, D.D. (1996) HIV-1 dynamics in vivo: Virion clearance rate, infected cell life-span, and viral generation time. Science, 271, 1582-1586.

Ramankulov, A., Lein, M., Kristiansen, G., Loening, S.A. \& Jung, K. (2007) Plasma osteopontinin comparison with bone markers as indicator of bone metastasis and survival outcome in patients with prostate cancer. Prostate, 67, 330-340.

Rodriguez, B., Sethi, A.K., Cheruvu, V.K., Mackay, W., Bosch, R.J., Kitahata, M., Boswell, S.L., Mathews, W.C., Bangsberg, D.R., 
Martin, J., Whalen, CC., Sieg, S., Yadavalli, S., Deeks, S.G. \& Lederman, M.M. (2006) Predictive value of plasma HIV RNA level on rate of CD4 T-cell decline in untreated HIV infection. JAMA, 296, 1498-1506.

Saitoh, H., Ashino, Y. \& Hattori, T. (2009) HAART improved prolonged, severe symptoms of fever and rash in a patient with acute HIV infection. Nippon Naika Gakkai Zasshi, 98, 167168.

Seki, M., Sakata, K.M., Oomizu, S., Arikawa, T., Sakata, A., Ueno, M., Nobumoto, A., Niki, T., Saita, N., Ito, K., Dai, S.Y., Katoh, S., Nishi, N., Tsukano, M., Ishikawa, K., Yamauchi, A., Kuchroo, V. \& Hirashima, M. (2007) Beneficial effect of galectin 9 on rheumatoid arthritis by induction of apoptosis of synovial fibroblasts. Arthritis Rheum., 56, 3968-3976.

Shinohara, M.L., Jansson, M., Hwang, E.S., Werneck, M.B.F., Glimcher, L.H. \& Cantor, H. (2005) T-bet-dependent expression of osteopontin contributes to T cell polarization. Proc. Natl. Acad. Sci. U.S.A., 102, 17101-17106.

Shinohara, M.L., Lu, L., Bu, J., Werneck, M.B.F., Kobayashi K.S., Glimcher, L.H. \& Cantor, H. (2006) Osteopontin expression is essential for interferon- $\alpha$ production by plasmacytoid dendritic cells. Nat. Immunol., 7, 498-506.
Smith, L.L., Cheung, H.K., Ling, L.E., Chen, J., Sheppard, D., Pytela, R. \& Giachelli, C.M. (1996) Osteopontin N-terminal domain contains a cryptic adhesive sequence recognized by $\alpha 9 \beta 1$ integrin. J. Biol. Chem., 271, 28485-28491.

Tamura, A., Shingai, M., Aso, N., Hazuku, T. \& Nasu, M. (2003) Osteopontin is released from the heart into the coronary circulation in patients with a previous anterior wall myocardial infarction. Circ. J., 67, 742-744.

Taooka, Y., Chen, J., Yednock, T. \& Sheppard, D. (1999) The integrin $\alpha 9 \beta 1$ mediates adhesion to activated endothelial cells and transendothelial neutrophil migration through interaction with vascular cell adhesion molecule-1. J. Cell Biol., 145, 413-420.

Theo, A., Masebe, T., Suzuki, Y., Kikuchi, H., Wada, S., Obi, C.L., Bessong, P.O., Usuzawa, M., Oshima, Y. \& Hattori, T. (2009) Peltophorum africanum, a traditional South African medicinal plant, contains an anti HIV-1 constituent, betulinic acid. Tohoku J. Exp. Med., 217, 93-99.

Zangerle, R., Steinhuber, S., Sarcletti, M., Dierich, M.P., Wachter, H., Fuchs, D. \& Möst, J. (1998) Serum HIV-1 RNA levels compared to soluble markers of immune activation to predict disease progression in HIV-1-infected individuals. Int. Arch. Allergy Immunol., 116, 228-239. 